\title{
Approaches to and tools for managing environmental conflicts in coastal zones in Africa: Challenges and prospects in relation to Integrated Coastal Zone Management (ICZM)
}

\author{
Fathima Ahmed ${ }^{*}$
}

\begin{abstract}
Conflicts in coastal zones arise as a result of the variance between divergent interests, within limited and dynamic socio-spatial and ecological dimensions, with little effort at critical consensus. Coastal zones worldwide exhibit three classical internal trademarks - high pressures for development, management weaknesses to protect coastal ecosystems and the deterioration of environmental conditions - all of which exacerbate conflicts over use and access of coastal zones. These conflicts are further expected to intensify against the backdrop of global climate change, with their location specific manifestations and impacts. Coastal zones in Africa are particularly vulnerable, as burgeoning population increases and rapid economic growth compound pressures on and intensify conflicts over scarce/stressed resources. Furthermore, the situation is particularly acute as deteriorating environmental conditions impede social and economic development, and are linked to the pervasiveness of hunger, poverty and disease, which engage in a vicious cycle of environmental conflicts. As coastal environments become excessively anthropocentric, ecological dimensions
\end{abstract}

* Dr Fathima Ahmed is lecturer in the Discipline of Geography, School of Environmental Sciences at the University of KwaZulu-Natal, Durban. 


\section{Fathima Ahmed}

cannot obviate the impact of human behaviour. Integrated approaches present powerful frameworks for analysing human-environmental conflicts, understood as ecological change, together with human knowledge and practice. Efforts at conflict resolution should be aimed at improving environmental conditions in tandem with improving the level of technical skill and capacity to mitigate environmental degradation. The challenge is to balance the need for short-term gains with long-term integrated resource management, heralded as Integrated Coastal Zone Management (ICZM). This article examines the challenges and prospects for approaches and tools to manage environmental conflicts in Africa's coastal zones.

\section{Introduction}

The concept of an ecosystem offers a constructive framework for examining the linkages between humans and the environment, as environmental conflicts are typified as combining high degrees of societal and ecological complexity and vulnerability (Wittmer et al. 2006:1). Homer-Dixon (1999, cited in Raleigh and Urdal 2007:677) elaborates on this complexity by asserting that society and ecology engage in reciprocal feedbacks, in a process referred to as 'resource capture and ecological marginalisation':

Resource capture occurs when the degradation and depletion of a renewable resource (a decrease in supply) interacts with population growth (an increase in demand) to encourage powerful groups within a society to shift resource access (that is, to change the resource's distribution) in their favour. These groups tighten their grip on the increasingly scarce resource and use this control to boost their wealth and power. Resource capture intensifies scarcity for poorer and weaker groups in society. Ecological marginalisation occurs when unequal resource access (skewed distribution) combines with population growth (an increase in demand) to cause long-term migrations of people to ecologically fragile regions...High population densities in these regions, combined with a lack of knowledge and capital to protect the local ecosystem, cause severe resource degradation (a decrease in supply). 


\section{Managing environmental conflicts in coastal zones in Africa}

Several authors concur that adverse environmental change falls disproportionally greater on the poor, worsening their risk to hazards, their wellbeing, and increasing the incidence of social conflict; all of which have dire implications on inter- and intra-generational equity (Parnell 2000:2; Millennium Ecosystem Assessment 2003:7; Brownlie et al. 2006:A-12). The interface between poverty and the environment is widely recognised as particularly important in Africa, which is considered as 'one of the world's most vulnerable natural and social regions' (Parnell 2000:1). It is advocated that mitigation of environmental conflict calls for approaches aimed at greater 'environmental entitlement' (increased access and social justice) accorded to the poor (Parnell 2000:8; Millennium Ecosystem Assessment 2003:14).

Integrated Coastal Zone Management (ICZM) is essentially about conflict resolution, as it takes place in a limited coastal space and water, where the amount of useable land and other resources available is limited, and where a plethora of interests converge and interact. The article draws on the premise of resource scarcity/stress of African coastal zones, recommending and reinforcing the desirability of managing coasts in an integrated manner by underscoring the importance of participatory approaches and extending societal contributions to incorporate spatial dimensions in decision support for ICZM. Spatial dimensions include land use change, physical attributes, perceptions related to land quality and suitability of existing and proposed activities. This article undertakes a desk top study focusing on the key debates and issues in relation to the use of specific approaches and tools for managing environmental conflicts in African coastal zones.

\section{Importance of coastal zones and increasing pressures}

Planet Earth is a coastal planet, on which land and sea interact intensively and extensively along the world's total $1634701 \mathrm{~km}$ of coastline (Martínez et al. 2007:255), producing the world's most unique and attractive areas. Coastal environments occupy one of the most dynamic interfaces between land and sea, and they support some of the most diverse and productive habitats (Mclean and Tsyban 2001:356). Furthermore coastal zones stand out as areas of extraordinary changes, shaped both by natural processes and human society which impact either 


\section{Fathima Ahmed}

directly on coastal processes and systems and/or indirectly through modification of the natural processes and global climate change (Land-Ocean Interactions in the Coastal Zone 2005:1). Coastal zones comprise specialised interdependent systems which are of particular importance - from environmental, social and economic points of view. Due to the many habitat types and wealth of genetic diversity, coastal ecosystems provide multiple services, which have recently been estimated as at least $40 \%$ of the value of the world's ecosystem services (Gattuso and Smith 2007:2). Their unique ecosystems are also important for biodiversity refuge and coastal protection. Furthermore, coastal zones act as both environmental regulators and sinks, presenting important feedbacks in land-coast interactions that determine thresholds and boundaries for system resilience to global environmental change (Turner et al. 1995:5). In addition, they are also important socio-economic zones, 'sustaining livelihoods through flows of income derived from the in situ utilisation of natural coastal capital and through global trading networks' (Turner 2004:2).

Coastal zones around the world share a number of characteristics that define both their significance and susceptibility - they have the world's highest population density, developed economies, and the most vulnerable environment (Shi and Singh 2003:145). Kenya, Tanzania and Mozambique, for example, provide stark examples of countries with most of the major towns and cities located in the coastal strip (Turner et al. 1995:7). Projected population growth to 2050 indicates a $98 \%$ growth expected from less developed regions with $35 \%$ from sub-Saharan Africa, the world's fastest growing region (Akegbejo-Samsons 2009:1). Some $60 \%$ of the world's human population live within about 100 kilometres of the shore (Turner 2004:1). Urban growth, as a result of migration in tandem with population growth is also expected to impact on African coastal cities as adverse agricultural conditions force people to seek employment in coastal cities (Akegbejo-Samsons 2009:1).

There are several generic non-demographic effects of climate change which are similar across a range of societal and geographic settings (prevalence of vulnerable livelihoods, poverty and weak states), which interact with population changes, resulting in subsequent disastrous impacts on coastal ecosystems, thereby intensifying recourse to possible conflict (Barnett and Adger 2007:643). 


\section{Managing environmental conflicts in coastal zones in Africa}

The variety of demands for utilisation and protection collide in this area making it a zone of conflicts, but also of potentials (Lourenço and Machado 2007:2), if managed appropriately.

\section{Types of coastal zone conflicts}

Kahl (2006, cited in Raleigh and Urdal 2007:678), building on the notion of resource scarcity, asserts that demographic and environmental stress (DES) attributed to the interaction between resource degradation, population growth and unequal resource distribution, puts significant pressure on both society and state institutions, providing fertile grounds for environmental conflicts. Kahl further distinguishes between two outcomes of DES: the weakening of the state's functional capacity, where the sheer scale of resource demands outweighs the ability of the state to meet these demands; and the weakening of the state's social cohesion, where elites within the state may compete over how to use strained resources either geographically or sectorally (Kahl 2006, cited in Raleigh and Urdal 2007:679). The conflicts relate to two key areas, coastal ecosystem change and coastal development, which are discussed below.

\section{Conflicts related to coastal ecosystem change}

In most countries coastal resources (coastal waters and beaches) are considered common property available equally to all citizens, with the government as 'trustee' (Jinn et al. 2003:139). This common property nature makes it impossible to exclude those who do not pay for using them, and as a result there is no incentive to conserve resources. As a result, overuse and exhaustion can occur when utilisation or harvest rates exceed the population growth rates of species or the ability of ecosystems to recover from disturbances (Jinn et al. 2003:139). Too often, traditional controls over the allocation and use of coastal space and coastal resources disintegrate when privatisation and/or markets and associated societal behaviours contrary to traditional controls become prevalent (Olsen and Christie 2000:7). Nielson et al. (2004:152) indicate that impacts on African fisheries are a significant example of such common property conflicts where their exploitation and markets are increasingly operating in the international domain and opportunities in globalisation are largely translating into exclusion. 


\section{Fathima Ahmed}

They assert that this has resulted in local fishing communities losing control over and access to the fisheries resources, as the case of foreign harvesting of shrimp along the Mozambican coast demonstrates.

Considerable portions of people in African countries depend on fish for protein, and thus near-term impacts on the fishery sector may also affect human nutrition and health (Akegbejo-Samsons 2009:6). Fisheries are also under pressure from other uses of the coastal and freshwater environment such as infrastructure, industrial development, aquaculture, tourism and other environmental changes. The result is the competition for space in ways that lead to reduced productivity of fisheries resources, as, for example, the development of tourism on Lake Kariba in Zimbabwe, which led to large areas being closed to fisheries by local communities (Jul-Larsen et al. 2002 cited in Nielson et al. 2004:152). The conversion of multiple-use coastlines to a single-use resource has given rise to social disruption and conflicts as it tends to displace other stakeholders and often also the traditional and community use of coastal space.

Habitat loss and degradation in coastal zones are occurring worldwide through activities such as reclamation projects, conversion of mangroves for aquaculture, and removal of coastal forests for development and agriculture (Nelson et al. 2006:8). Aquaculture, the world's fastest growing food production activity, plays an essential role in the livelihoods of millions of people (Creel 2003:4). Aquaculture and fisheries provide sources of nutrition, foreign exchange earnings and employment, but also have negative social, economic and environmental consequences such as loss of ecosystem services with regard to coastal protection and waste processing, loss of livelihoods of people, intensive groundwater abstraction and consequent pressures for water for local communities, pollution due to effluent discharge and depletion of the wild stock due to disease outbreaks in association with the introduction of exotic species (Burke et al. 2001:7).

The contributions of these 'free' ecosystem goods and services to national economies (including well-being) are substantial, yet they are generally ignored or underestimated by decision-makers (International Union for Conservation of Nature 2007:1). The costs of externalities associated with loss of ecosystem goods and services tend to be considerable (Van den Bergh 2000:5). This is 


\section{Managing environmental conflicts in coastal zones in Africa}

particularly acute in coastal zones due to a lack (or absence) of adequate market price data, together with inadequate (or absent) property rights regimes which ensure that resource values can be practicably appropriated, thereby assigning ecosystem services with little or zero value and weight in policy decisions (Jinn et al. 2003:139).

\section{Conflicts related to coastal development}

People in developed coastal areas rely heavily on infrastructure to ensure their safety against natural hazards and to support their well-being. Pressures from the urbanisation of coasts and the support of principles of sustainable development by many Southern African states have added to the challenge to local authorities and society who are already battling to cope with the contradictory demands associated with ensuring economic growth, service provision, preventing social exclusion and maintaining local democracy (Parnell 2000:15). According to Glavovic and Boonzaier (2007:1), confronting poverty and social equity are arguably the most challenging issues facing the South African government, and the coast has a significant role in meeting basic needs and improving the wellbeing of coastal communities, where $40 \%$ of the country's population is located. A situation analysis conducted by the United Nations Development Programme (UNDP) reveals that South Africa has persistently high unemployment, poverty, high HIV/AIDS infection rates, a dual formal/ informal economy, a low skills base and wide urban/rural disparities (United Nations Development Programme 2006:2). Given the value of the coast, these areas offer development opportunities (primarily port facilities, roads and housing) which may promote local and regional economic development (Department of Environmental Affairs and Tourism 2006:170). However, as Parnell (2000:15) states, across the Southern African region, the situation is fraught with problems, as the cost of political transition has diminished the staff of even the functional municipalities.

Infrastructure investment, mainly in pollution prevention issues, such as sewerage, wastewater and solid waste management, has fallen behind schedule due to the lack of adequate planning, legislation and financing in many countries (Burak et al. 2004:519), resulting in pollution of groundwater, water courses and coastal waters from untreated sewer and other contaminants. Iwugo et al. 


\section{Fathima Ahmed}

(2003:122-123) assert that poor industrial wastewater disposal and sanitation practices in Lagos have led to severe water scarcity as a result of pollution. Water-related diseases can further lead to health problems in Lagos as well as neighbouring areas and countries using the same coastal waters, because water pollution has no boundaries (Iwugo et al. 2003:122-123). This could potentially lead to inter-state conflicts.

Parnell (2000:16) further cautions that there exists a wide gap between 'the predominately green agendas of many official agencies and the agendas of community groups, who do not necessarily use the language of environment (green or brown), even when they are mobilising around questions of water, waste and pollution'. For many poor, day-to-day survival is a priority - this difference in priorities has been dubbed the issue of class and power in the articulation of environmental conflicts' (Blowers 1997, cited in Dastidar 2007:2). Conversely, the impacts of human actions on ecosystems are often slow to become apparent and hence ecosystems are managed in ways that benefit the short-term, while long-term costs go unnoticed or are ignored (Greenfacts 2005:5). This combination of time lag and absence of strategic thinking can transfer the costs of current changes to future generations.

Urban development in many coastal regions has led to increased shoreline modification and destruction and degradation of terrestrial and aquatic habitats (Grimm et al. 2008:265). With more than one-quarter of the population in Eastern and North Africa living within 100 kilometres of the coast and most cities concentrated along the coastline, the vulnerability to climate change disaster from sea level rise, tidal waves and storm surges will increase (Vordzorgbe 2007:1). Snoussi and Aoul (2000:1033) indicate that the development of industrial and tourism activities specifically in the Northwest African region has generally been highly concentrated in the coastal zone. The impacts on livelihoods are likely to be more significant to population with high resource-dependency, and people in more environmentally and socially marginalised areas (Barnett and Adger 2007:643). Coastal zones also attract a high proportion of migrants searching for employment opportunities in coastal cities, but many are without homes and proper sanitation, and such large-scale movements of people may increase the risk of conflict in host communities (Barnett and Adger 2007:643). 


\section{Managing environmental conflicts in coastal zones in Africa}

Many of the world's coasts have become committed to development, where economics strongly influence how trade-offs in coastal development are rationalised and decisions are made over resources, and where there are important preferences in allocating funds, resources and lands (International Union for Conservation of Nature 2007:2). In most developing countries, the authority and the responsibility to manage such resources are not vested in local institutions but in distant governmental agencies and powerful private interests, which results in 'winners' and 'losers' in allocation and use of resources (Olsen and Christie 2000:9). According to Martinez et al. (2007:267), in general, countries with high population densities on the coast had the lowest coastal ecosystem service product values ('highly degraded') because of intense exploitation of coastal resources.

Despite the complexity, coastal systems are mostly managed by agencies with single-resource or single-sector approaches, often acting independently. As noted by Cicin-Sain et al. (2000:293), this management model of sectoral atomisation is 'a carryover from the time when ocean resources were viewed as unlimited and ocean uses as independent of one another'. In addition, management authority is shared by various administrative bodies whose domains of action overlap, and whose territories of competence generally do not correspond to the ecological and human scales of the problems, leading to a geographical atomisation (Bille and Mermet 2002:915). This breeds unsustainable, or at least greatly suboptimal, development (Bille and Mermet 2002:915).

\section{Management challenges and opportunities}

Stojanovic and Ballinger (2009:49) assert that the effectiveness of institutional arrangements and policies for governance have become key questions within the sustainability paradigm. With regard to coastal and marine areas, ICZM has been discussed as a possible governance concept. Many African countries have implemented ICZM strategies to manage their coastal zones. Although definitions differ, the common theme traversing definitions of ICZM initiatives is that of sustainability. Ahmed (2006:34) states that ICZM is increasingly an accepted management framework to address coastal and marine environmental 


\section{Fathima Ahmed}

conflicts and establish management needs which are aimed at achieving sustainable use of coastal resources.

In Namibia, ICZM places emphasis on the integration of management structures and procedures by investing in human and technical capacity building and the coordination of sectoral interests, where benefits are understood to translate through improved efficiencies and better coordination (Parnell 2000:14). In Mozambique, ICZM was designed to link directly to other national development strategies, which are based on sector specific coastal action (for example, fishing, transport or tourism), that was designed to meet general development objectives as well as to protect the coast (Parnell 2000:14). In South Africa, the ICZM programme is explicitly committed to a pro-poor focus, in an attempt to redress the flaws of apartheid inequalities which denied the majority of people rights to the coastline and its resources, as well as to the economic opportunities provided by coastal development and infrastructure (Glavovic and Boonzaier 2007:2-4).

According to Olsen (2003:348), ICZM initiatives designed to advance specific coastal contexts towards coastal management must be designed to be sustainable over long periods of time (often several decades), be adaptable to rapidly changing conditions, and provide the mechanisms to encourage or require particular forms of resource use and collaborative behaviour among institutions and user groups. Community participation (including the different knowledges of the coast) is essential for any ICZM programme to be effective. On the one hand, effective ICZM is important to improve the well-being of communities who depend on coastal resources now and in the future while, on the other hand, ICZM needs to coordinate and mediate conflicts emanating from the different users and functions of the coastal zone (Hale et al. 1998:6). Furthermore, according to Xiuwan (2002:107), policy and decision making in the context of sustainable development require rapid, effective and efficient access to and integration of appropriate current information from a wide range of sources and disciplines, including spatial information (such as land cover change) which can demonstrate the potential in monitoring progress towards sustainable development. Adopting a spatial analytical approach can also inform good governance that contributes to sustainable development. 


\section{Managing environmental conflicts in coastal zones in Africa}

Developing suitable and reliable information which is easily accessible and consultable according to management objectives and capable of lending support to strategic decision making regarding likely environmental change that takes place in coastal zones is paramount (Trujillo et al. 2003:1). Sardá et al. (2005:427) underscore the importance of environmental information systems in ICZM processes. They specifically developed decision support tools as a methodological approach for coastal management which includes

- the development of an environmental indicator-based report;

- the use of the geographic information system (GIS); and

- the incorporation of different types of graphical packages.

They stress the importance of spatial tools and information for decision making and management.

By reviewing secondary literature and providing a synthesis of the ideas in existing studies of coastal management, Stojanovic et al. (2004:283) identify important factors for successful ICZM which include:

Comprehensiveness: an approach of taking a sufficiently wide scope and full view of issues, including cumulative impacts, given that ICZM seeks to consider the coastal zone as a system of interconnectedness. The authors cite Cicin-Sain and Knecht (1998) who outline various dimensions to comprehensiveness which include setting geographical boundaries for initiatives and the level of decision making at different geographical scales, specifically in terms of identifying actors/stakeholders and political responsibility for decision making (Stojanovic et al. 2004:283).

- Participation: a process by which there are opportunities for common contribution and balanced sharing of activities by interested parties. Participation is important since there is general consensus that if people participate in the process of taking a decision or developing a plan, they are more likely to support it. Participation also provides avenues for sharing of information and learning.

- Cooperation: a process by which agencies operate together and are coordinated to one end. The basic premise is that more can be achieved when individuals or groups work together towards a common goal. 


\section{Fathima Ahmed}

- Contingency: an approach that seeks to account for local variations in strategy, environment or task. Contexts differ and it is possible that variations may account for or be related to certain causes.

- Precaution: an approach or activities undertaken in advance to protect against possible danger or failure. Specifically, anticipating and predicting the likely causes of environmental degradation, rather than reacting to their outcome, should mean that environmental management prevents the costs that originate in rectifying damages.

- Long-termism: an approach that recognises that environmental management needs more than brief views of environmental circumstances to understand and manage the links between the human and natural environment. This includes understanding how environmental changes are buffered by externalities, whether reactions are incremental or related to thresholds, and how antecedent conditions affect coastal change.

- Focusing: a 'structured consideration of a problem in which an individual attends to the present experience' (Kantor and Zimring 1976:74, cited in Stojanovic et al. 2004:287). In this regard, stakeholder decision analysis and focus groups (workshops in particular) are identified as key tools for focusing on which aid groups of decision-makers (and other stakeholders) to identify and prioritising important environmental issues at the coast. In part, this research adopted this methodological approach together with other data collection techniques.

- Incrementalism: a recognition that management is an iterative process that proceeds in a step-by-step manner. This approach seeks to be realistic and pragmatic in that environmental management that takes a stepwise development will have greater opportunity to incorporate disseminated experience and make detailed assessments on important issues, whilst returning to neglected implications later.

- Adaptability: a more flexible and experimental approach that encourages greater social responsibility from those involved in management. It can increase capacity since it has a high learning element. Additionally, information is viewed as both a basis and a product for action. 


\section{Managing environmental conflicts in coastal zones in Africa}

These ideas are further supported in the South African National Environmental Management: Integrated Coastal Management Act (Act No. 24 of 2008) (Republic of South Africa 2009), and highlighted by Celliers et al. (2009:3-7) in their guide to this Act.

PROCOAST (2000, cited in Banica et al. 2003:38) has outlined the following areas as a constraint to ICZM initiatives: the separation of terrestrial and marine components of the coastal zone from the legal and institutional point of view; sectoral approaches of economic development planning and management of coastal areas and resources; lack of cohesion and consistency in policies, planning, investment and management strategies at different administrative levels; and lack of political awareness of the strategic importance of coastal areas and resources. While the argument for integration is theoretically compelling, in practice, these principles are seldom realised, largely as a result of political and institutional weaknesses (Burak et al. 2004:516). Francis and Torell (2004:300) concur and have attributed the proliferation of a wide range of anthropogenic disturbances in the Indian Ocean Region to poorly planned economic development, under-resourced government institutions, and weak implementation of existing policies and laws. This suggests that in order for ICZM to work efficiently, it requires political buy-in.

\section{Conclusion}

Administration and policy for coastal zone management, which will promote sustainable development, is clearly an important part of addressing coastal conflicts (both existing and potential) given the increased demands on our coasts, the potential for increased points of contestation relating to climate change, and the vulnerability of both people and ecosystems that reside there. ICZM in Africa is increasingly becoming recognised as an appropriate approach towards this aim. With reference to the literature reviewed and findings presented, the key problem in relation to the nature of information required for coastal zone management lies not so much in the provision or the content of the information itself, but in the way it is presented to those who formulate and implement policy and take management decisions. This study has also indicated that stakeholder input into decision making is crucial, and can go a long way to either support 


\section{Fathima Ahmed}

or reject policy implementation and management in the area. The continuation of the current trajectory is likely to yield large amounts of conflict, which will eventually undermine sustainable development. An integrated perspective is therefore immediately required.

\section{Sources}

Ahmed, A.K. 2006. Concepts and practices of resilience: A compilation from various secondary sources. Paper prepared for the Coastal Community Resilience Programme, US Indian Ocean Tsunami Warning System (IOTWS) Programme, Bangkok.

Akegbejo-Samsons, Y. 2009. Demographic trends, resource allocation and climate change in sub-Saharan Africa: Policy implications for sustainability. Available from: $<\mathrm{http}: / / \mathrm{www}$. openmeeting2009.org/pdf_files/Pdf\%20papers/Full\%20paper\%20IHDP\%202009\%20 A\%20version.pdf $>$ [Accessed 15 February 2010].

Banica, A., J. Bastard and M. Kosiek 2003. Integrated Coastal Zone Management (ICZM): A framework to tackle environmental issues? Danish Approach. Published Thesis, Centre for Environmental Studies, The University of Aarhus, Denmark.

Barnett, J. and W.N. Adger 2007. Climate change, human security and violent conflict. Political Geography, 26, pp. 639-655.

Bille, R.L. and L. Mermet 2002. Policy and practice: Sectoralisation of an Integrated Coastal Management Programme: A case study in Madagascar. Journal of Environmental Planning and Management, 45, pp. 913-926.

Brownlie, S., B. Walmsley and P. Tarr 2006. Guidance document on biodiversity, impact assessment and decision making in Southern Africa. Compiled by the Southern African Institute for Environmental Assessment, as part of the Capacity Building in Biodiversity and Impact Assessment project of the International Association for Impact Assessment (IAIA).

Burak, S., E. Dogan and C. Gazioglu 2004. Impact of urbanisation and tourism on coastal environment. Ocean \& Coastal Management, 47, pp. 515-527.

Burke, L.A., Y. Kura, K. Kassem, C. Revenga, M. Spalding and D. Mcallister 2001. Coastal Ecosystems. Washington, DC, World Resources Institute.

Celliers, L., T. Breetzke, L. Moore and D. Malan 2009. A User-friendly guide to South Africa's Integrated Coastal Management Act. The Department of Environmental Affairs and SSI Engineers and Environmental Consultants, Cape Town, South Africa.

Cicin-Sain, B. and R. Knecht 1998. Integrated coastal and ocean management: Concepts and Practices. Washington, DC, Island Press.

Cicin-Sain, B., R.W. Knecht, A. Vallega and A. Harakunarak 2000. Education and training in integrated coastal management: Lessons from the international arena. Ocean and Coastal Management, 43, pp. 291-330. 


\section{Managing environmental conflicts in coastal zones in Africa}

Creel, L. 2003. Ripple effects: population and coastal regions. Washington, DC, Population Reference Bureau.

Dastidar, S. 2007. The Poverty of Environmental Planning. London, Development Planning Unit, University College.

Department of Environmental Affairs and Tourism 2006. South African Environment Outlook: A report on the State of the Environment. Chapter 7. Pretoria, Department of Environmental Affairs and Tourism.

Francis, J. and E. Torell 2004. Human dimensions of coastal management in the Western Indian Ocean region. Ocean and Coastal Management, 47, pp. 299-307.

Gattuso, J. and S.V. Smith 2007. Coastal zone. In: Cleveland, C.J. ed. Encyclopedia of Earth. Washington, DC, Environmental Information Coalition, National Council for Science and the Environment.

Glavovic, B.C. and S. Boonzaier 2007. Confronting coastal poverty: Building sustainable coastal livelihoods in South Africa. Ocean and Coastal Management, 50, pp. 1-23.

Greenfacts. 2005. Scientific facts on ecosystem change. Available from: $<$ http://www.greenfacts. org/> [Accessed 24 March 2008].

Grimm, N.B., D. Foster, P. Groffman, J.M. Grove, C.S. Hopkinson, K.J. Nadelhoffer, D.E. Pataki and D.P.C. Peters 2008. The changing landscape: Ecosystem responses to urbanisation and pollution across climatic and societal gradients. Frontiers in Ecology, 6, pp. 264-272.

Hale, L., E. Meltzer and M. Ngoile 1998. Application of international experience to formulation of a national policy for coastal management for the Republic of South Africa. In: Coastal Management Policy Programme, Lessons Learnt from Past Experience. Cape Town: Coastal Management Policy Programme.

International Union for Conservation of Nature 2007. Natural ecosystems as coastal development infrastructure, The World Conservation Union, 5. Available from: $<\mathrm{http}: / /$ iucn.org/coastalinfo/> [Accessed 4 July 2008].

Iwugo, K.O., B. D’Arcy and R. Andoh 2003. Aspects of land-based pollution of an African coastal megacity of Lagos. Diffuse Pollution Conference, Dublin 2003 Poster Papers.

Jinn, J., Z. Wang, S. Ran and C. Yun 2003. Study on coastal resource evaluation theories and methods. International Conference on Estuaries and Coasts. Hangzhou, China.

Land-Ocean Interactions in the Coastal Zone 2005. Science Plan and Implementation Strategy. International Geosphere-Biosphere Programme (IGBP) Report 51/IHDP Report 18. Stockholm, IGBP Secretariat.

Lourenço, N. and C.R. Machado 2007. Understanding territory dynamics in coastal areas: A methodological approach to analyse socio-economic and biophysical interactions. ENCORA, $1^{\text {st }}$ Thematic Network Conference, Venice, Italy, 12-13 March.

Martinez, M.L., A. Intralawan, G. Vazquez, O. Perez-Maqueo, P. Sutton and R. Landgrave 2007. The coasts of our world: Ecological, economic and social importance. Ecological Economics, 63, pp. 254-272. 


\section{Fathima Ahmed}

Mclean, R.F. and A. Tsyban 2001. Coastal zones and marine ecosystems. In: McCarthy, J.J., O.F. Canziani, N.A. Leary, D.J. Dokken and K.S. White 2001. Climate change 2001: Impacts, adaptation, and vulnerability. Cambridge, Cambridge University Press.

Millennium Ecosystem Assessment 2003. Ecosystems and human well-being. Washington, DC, Island Press.

Nelson, G.C., E. Bennett, A.A. Berhe, K. Cassman, R. DeFries, T. Dietz, A. Dobermann, A. Dobson, M. Janetos, D. Levy, N. Marco, B. Nakicenovic, R. O’Neill, G. Norgaard, D. PetschelHeld, P. Ojima, R. Watson and M. Zurek 2006. Anthropogenic drivers of ecosystem change, ecology and society, 11. Available from: <http://www.ecologyandsociety.org/vol11/iss2/ $\operatorname{art29/>~[Accessed~} 20$ July 2008].

Nielsen, J.R., P. Degnbol, K.K. Viswanathan, M. Ahmed, M. Hara and N.P.R. Abdullah 2004. Fisheries co-management - an institutional innovation? Lessons from South East Asia and Southern Africa. Marine Policy, 28, pp. 151-160.

Olsen, S. and P. Christie 2000. What are we learning from tropical coastal management experiences? Coastal Management, 28, pp. 5-18.

Olsen, S.B. 2003. Frameworks and indicators for assessing progress in integrated coastal management initiatives. Ocean and Coastal Management, 46, pp. 347-361.

Parnell, S. 2000. Environment and poverty in Southern Africa - regional linkages. Background Paper prepared for DFID (Department for International Development, United Kingdom) SA and CA, November 2000.

Raleigh, C. and H. Urdal 2007. Climate change, environmental degradation and armed conflict. Political Geography, 26, pp. 674-694.

Republic of South Africa 2009. National Environmental Management: Integrated Coastal Management Act, Act No. 24 of 2008. Cape Town, Government Printer.

Sárda, R., C. Avila and J. Mora 2005. A methodological approach to be used in integrated coastal zone management processes: The case of the Catalan Coast (Catalonia, Spain). Estuarine Coastal and Shelf Science, 62, pp. 427-439.

Shi, H. and A. Singh 2003. Status and interconnections of selected environmental issues in the Global Coastal Zones. Ambio, 32, pp. 145-152.

Snoussi, M. and E.H.T. Aoul 2000. Integrated coastal zone management programme: Northwest African region case. Ocean and Coastal Management, 43 (12), pp. 1033-1045.

Stojanovic, T.A. and R.C. Ballinger 2009. Integrated Coastal Management: A comparative analysis of four UK initiatives. Applied Geography, 29, pp. 49-62.

Stojanovic, T., R.C. Ballinger and C.S. Lalwani 2004. Successful integrated coastal management: Measuring it with research and contributing to wise practice. Ocean and Coastal Management, 47, pp. 273-298.

Trujillo, A.J., J. Pino and F. Breton 2003. The role of coastal zone information systems in a socioenvironmental change study within a spatio-temporal and interdisciplinary approach: A case study of the Catalonian coastal zone. Presentation at Integrating information in 


\section{Managing environmental conflicts in coastal zones in Africa}

Coastal Zone Management - Fifth International Symposium on GIS and Computer Cartography for Coastal Zone Management, Palazzo Ducale, Genova, Italy, 16-18 October.

Turner, K. 2004. Integrated environmental assessment and coastal futures. In: Vermaat, J., L. Bouwer, K. Turner and W. Salomons eds. 2005: Managing European coasts: Past, present and future. New York, Springer.

Turner, R.K., S.E. Subak and W.N. Adger 1995. Pressures, trends and impacts in the coastal zones: Interactions between socio-economic and natural systems. Centre for Social and Economic Research on the Global Environment (CSERGE) Working Paper GEC 95-09 on the Global Environment, University of East Anglia, and University College London.

United Nations Development Programme (UNDP) 2006. Country programmes and related matters. Draft country programme document for South Africa (2007-2010), Second regular session, New York.

Van den Bergh, J.C.J.M. 2000. Ecological economics: Themes, approaches, and differences with environmental economics. Department of Spatial Economics: Free University (Netherlands), Amsterdam.

Vordzorgbe, S.D. 2007. Climate change and risk management in Africa: Major issues. United Nations International Strategy for Disaster Reduction (UN/ISDR), Expert Background Paper for the Session on Risk Management and Climate Change, World Economic Forum on Africa, Cape Town, 13-15 June.

Wittmer, H., F. Rauschmayer and B. Klauer 2007. How to select instruments for the resolution of environmental conflicts? Political Geography, 26, pp. 674-694.

Xiuwan, C. 2002. Using remote sensing and GIS to analyse land cover change and its impacts on regional sustainable development. International Journal of Remote Sensing, 23, pp. 107-124. 